Article

\title{
The Role of Sustainability Key Performance Indicators (KPIs) in Implementing Sustainable Strategies
}

\author{
Ivo Hristov * (D) and Antonio Chirico \\ Department of Management and Law, University of Rome Tor Vergata, 00133 Rome, Italy; \\ chirico@economia.uniroma2.it \\ * Correspondence: hristov@economia.uniroma2.it; Tel.: +39-06-7259-5751
}

Received: 7 September 2019; Accepted: 16 October 2019; Published: 17 October 2019

\begin{abstract}
The role of sustainability dimensions in the value creation process has attracted considerable interest in the scientific academic world in the last two decades. The 2030 Agenda, which fixed the sustainable goals (SDGs) to safeguard our planet, highlighted the fundamental role of sustainability issues. In this context, companies around the world need to integrate their strategies with environmental, social, and economic dimensions. However, sustainability aspects are often not linked to company strategies, and there has been growing difficulty in measuring sustainable development by adopting an appropriate set of key performance indicators (KPIs). Accordingly, the aim of this study is as follows: (1) to identify the suitable KPIs that affect company performance, based on the literature and management practices, and (2) to propose a new perspective on a way to integrate sustainability issues in company strategies. Based on a systematic procedure, we obtained 82 papers that focus on KPIs related to sustainability issues. Following a review of papers and a survey conducted with Italian managers, we developed a sustainability perspective by selecting the most appropriate KPI system for each of the dimensions discussed. The proposed model suggests that incorporating sustainability dimensions within corporate strategy would allow strategic alignment in order to gain competitive advantage and therefore create sustainability value.
\end{abstract}

Keywords: sustainability; SBSC; performance management; key performance indicators

\section{Introduction}

The tendency to create value in a sustainable way assumed a relevant role in the strategies of companies that aim to achieve high-quality performance while respecting natural resources. Different challenges, with a focus on people, the planet, prosperity, and collaboration, represent goals to achieve in order to improve people's way of life [1]. The change should start from individuals, and therefore from companies, which represent the fulcrum of global growth. In particular, in 2015 the world further confirmed its commitment with the 2030 Agenda for Sustainable Development, which represents an action program for people, the planet, and prosperity aimed at improving life and individual well-being. Reducing poverty in all its forms and dimensions, including extreme poverty, is the biggest global challenge and a prerequisite for sustainable development. The sustainable bioeconomy strategy represents the renewable segment of the circular economy and assumes a fundamental role in this context. In particular, its implementation would allow us to turn bio-waste and discards into precious resources. According to the European Commission [2], this strategy would impact the value creation process in several aspects regarding modernization and innovation, food security, clean energy, climate change, healthy ecosystems, job creation, mobilization of public and private stakeholders, environmental performance information, and renewable resources. Therefore, a circular 
development strategy could lead to relevant economic and sustainable gains. However, it is fundamental to adapt a strategic and systemic approach to the deployment of innovations in order to fully utilize the environmental, social, and economic advantages of the bioeconomy and sustainable implementation.

In this context, a relevant role is played by a strategic tool that allows integration of sustainability dimensions and a performance management system (PMS), in order to incorporate all sustainability goals into a company's strategy. Particularly relevant are issues concerning the creation of sustainable value, which are only partially reflected in economic transactions, although they have become increasingly important for today's businesses.

The growing attention to sustainability issues [3-5] drives companies to integrate objectives of all three dimensions into their strategy [6]. The effort to integrate sustainability and strategy is growing constantly, but it is not always intuitive [7]. With regard to key performance indicators (KPIs), numerous studies have explored sustainability KPIs and investigated their usefulness [8-11]. However, as far as we know, the literature does not provide an updated review on the subject selecting the most relevant KPIs that are useful for evaluating a firm's sustainability value. In addition, these studies do not provide exhaustive evidence from managerial practices.

In this context, the aim of our study is to identify a suitable set of KPIs to manage sustainability issues, and to identify a way to make selected KPIs an integral part of a company's strategy. To this end, we devoted our attention to two main research questions:

(1) What is the set of KPIs that best represent all facets of sustainability dimensions?

(2) How do we integrate sustainability dimensions into the strategy of the company?

Accordingly, with regard to the first question, we analyzed the literature to identify a comprehensive set of KPIs that can help managers develop performance strategies in terms of sustainability and conducted a systematic literature review (SLR). We analyzed all papers obtained in depth and selected all KPIs connected to our research question. Moreover, we analyzed the sample of papers by using bibliometric software, which provided interesting descriptive statistics related to the keywords and citations. In addition, we conducted a survey of Italian managers considering a practical point of view based on their experience.

With regard to the second question, based on the interviews with managers, we discussed potential solutions and surmised that an additional sustainability perspective based on the Sustainability Balanced Scorecard (SBSC) framework would be particularly efficient at driving companies toward integrating sustainability dimensions into their strategies.

Our paper contributes to the literature in several ways. First, our research adds to the existing literature because it allows us to standardize a comprehensive set of KPIs connected to sustainability dimensions and provide an updated literature review on the subject. In addition, we provide a practical point of view based on management experience. Lastly, results suggest that considering the new perspective makes it possible to build a new model to integrate strategy with environmental, social, and economic issues.

In the next sections, we summarize the prior research findings, then describe our research methodology and discuss our findings. We finally draw main conclusions from our work and we propose suggestion for future research.

\section{The Role of the SBSC in Sustainability Value Creation}

The growing strategic importance of issues related to sustainability and connected performance measures has stimulated interest regarding the relationship between sustainability dimensions and PMSs. Many organizations have started to implement sustainable management systems; however, they are rarely adequately integrated into the companies' strategy. Consequently, environmental and social dimensions have often been disconnected from financial performance, leaving the contribution made by this economic success unclear. The decisive role of companies in achieving sustainability has been emphasized and discussed at both strategic [12-14] and operational $[15,16]$ levels. In this context, 
one of the most relevant strategic system that has received enormous consideration by researchers and practitioners is the SBSC. This tool aims to integrate all business levels inside the company, translating strategies into goals and specific KPIs $[17,18]$. The SBSC, in fact, has often been associated with sustainability in an attempt to integrate it with organizational performance. In the literature, several researchers used the SBSC in different fields in order to improve a company's strategy [19-21]. To this end, the tool can be considered very useful to capture different dimensions in strategy implementation and therefore could be an effective system to promote sustainability culture in businesses [22-25].

Several authors highlight how the SBSC can be structured in order to affect company performance, with particular attention paid to the set of KPIs to select. The literature has largely contributed, and continues to contribute, to highlighting the role of the SBSC for integrating strategy with CSR. Particular attention is needed to select the appropriate KPIs, which is one of the most problematic issues in implementing an efficient sustainability system. According to Hristov et al. [6], the traditional structure of the tool can be modified by considering a new basic dimension, called critical, that includes all critical aspects connected to the SBSC. The authors also consider criticism connected to sustainability dimensions, suggesting that they can be considered into a strategy according to a new perspective by modifying the structure of the SBSC as an Adjusted Sustainability Balanced Scorecard (ASBSC).

\section{Research Methodology}

In order to identify the most relevant KPIs that allow integrating sustainability into a company's strategy, the study was conducted with two data sources, SLR and survey [26-30].

\subsection{Literature Review Procedure}

We followed this method to ensure a rigorous process involving all authors during the research steps of the analysis. The main database that we searched was Scopus. The keywords used for the selection of articles were as follows: "Sustainability" or "Environmental" or "Social", or "SBSC" or "Sustainable", and "KPI" or "Key Performance Indicator" or "Index" or "Benchmark" in the article title, abstract, and keywords. Only peer-reviewed articles written in English were selected, excluding, for example, book chapters, doctoral dissertations, and research reports. In particular, we eliminated duplications and excluded papers if they were published in journals not focused on business management and accounting or economics. In the first step of our research, we obtained a total of 971 papers from the initial search. In the second step, we analyzed each paper's title, abstract, and keywords to decide whether or not to include the paper for further analysis. We selected only papers that focused on the role of KPIs in sustainability dimensions. In order to ensure validity and reliability of checks done in selecting the abstracts, the authors worked together following a specific procedure. For example, all authors skimmed the abstracts. Then they worked separately reading these papers and reported their main contents on a detailed table. An initial review of 971 papers netted 179 studies that we considered were in the field of research. In the last screening evaluation, the selection was based on the full text by examining the contents in depth, to ensure that all selected papers specifically focused on sustainability issues related to KPIs used in order to lead companies in the value creation process. Based on this approach, 82 papers were finally identified and analyzed (Figure 1). The time period chosen for searching the most relevant articles was from 1999 to 2019. This period confirmed a steady increase in the emphasis on sustainability dimensions to support strategic management tools and therefore PMSs [23,24,31,32].

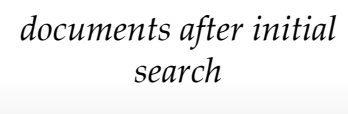

971
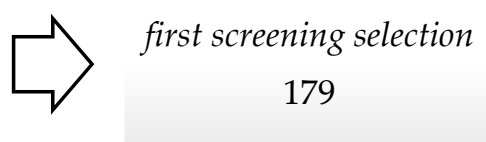

179

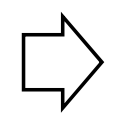

Figure 1. Systematic analysis results. secondary screening
selection

82 


\subsection{Survey Methodology}

In order to reinforce our contribution to the literature and provide the practical implications of our model, we selected a sample of managers who specialized in KPIs used in sustainable development $[33,34]$. The managers played a fundamental role in providing suggestions for future research based their experience in the field. Using LinkedIn and personal contacts, we sent a first questionnaire, composed of 10 questions, to 97 managers in order to identify some of their basic information and their experience with KPIs and sustainability issues. The survey was divided into two parts: the first was aimed at revealing demographic aspects, and the second was aimed at determining obtaining about knowledge of the SBSC and use of sustainability dimensions and indicators. We obtained a total of 64 responses and selected only managers with a high level of experience (more than 5 years using KPIs connected to sustainability dimensions); their ages ranged from 40 to 60 years. Our final sample was composed of 25 managers who confirmed their availability to be interviewed (Figure 2). We informed managers by e-mail of the main purposes of our study. In the second step of this process, we interviewed our sample managers. Each interview, by phone or Skype, lasted 32 minutes on average (ranging from 25 to $39 \mathrm{~min}$ ), and all were transcribed and coded for analysis. The interview questionnaire (Appendix A) was composed of five sections, aimed to (1) identify the strategic goals to include in each sustainability dimension; (2) select the appropriate KPIs for each goal; (3) identify possible competitive advantages from implementing a sustainable strategy; (4) understand how the managers evaluate performance in terms of sustainability value creation; and (5) analyze the role of the SBSC in accounting for these dimensions. All data were analyzed by categorizing the responses into major conceptual macro areas. Finally, we improved the validity of the process by asking the respondents to check their transcribed interviews for the information obtained and to highlight possible errors [35]. At the same time, we triangulated all data obtained by the interviews and the secondary data [36,37].
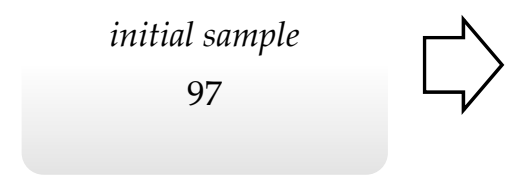

$$
\begin{aligned}
& \text { total respondents } \\
& 64(65 \%)
\end{aligned}
$$

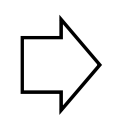

sample selected $25(39 \%)$

Figure 2. Sample selection results.

\section{Research Findings}

We divided our research findings into three sections. First, we provided the outcome of the SLR using bibliometric mapping with regard to the methodological aspects. In the second step, we analyzed the KPIs discussed in the literature. Finally, we analyzed the role of sustainability KPIs based on management experience in order to define a clear picture of the most relevant indicators to use in order to achieve a sustainable strategy.

\subsection{Bibliometric Analysis}

In the next step of our work, we developed a bibliometric analysis for the relevant articles. This kind of analysis is widely applied in different fields [38], as it examines information in articles to investigate relevant issues in quantifiable ways [39]. In particular, we exported all the relevant publications for our research questions, and further organized them in single Excel papers. Articles were extracted by Scopus in comma-separated values (CSV) format on Excel and organized by year of publication, starting with new releases, then older ones. Specific information was disclosed and further organized in order to obtain a complete understanding of the paper to be analyzed. This phase is fundamental for data synthesis. For this reason, the sample obtained was inserted in a specific system in order to summarize in graphical form the results achieved and their main characteristics. The exported CSV files were subsequently uploaded on VOSviewer [40-43], a system able to analyze intercorrelations between papers, their abstracts, keywords, authors, and so on. In fact, VOSviewer represents scientific 
software for building and visualizing all existing bibliometrics networks and linkages. However, it is important to underline that the system is ability to create text mining functionality in order to visualize correlated and often recurring networks of fundamental keywords extrapolated from the overall body of academic literature, so that relevant bibliometrics interconnections can be constructed. Figure 3 shows the existing networks in terms of the most recurring keywords created by the system on the basis of the selected scientific publications. In particular, it can be seen that "sustainability", "key performance indicators", "benchmarking", and "sustainable development" were the most frequent keywords in the sample analyzed.

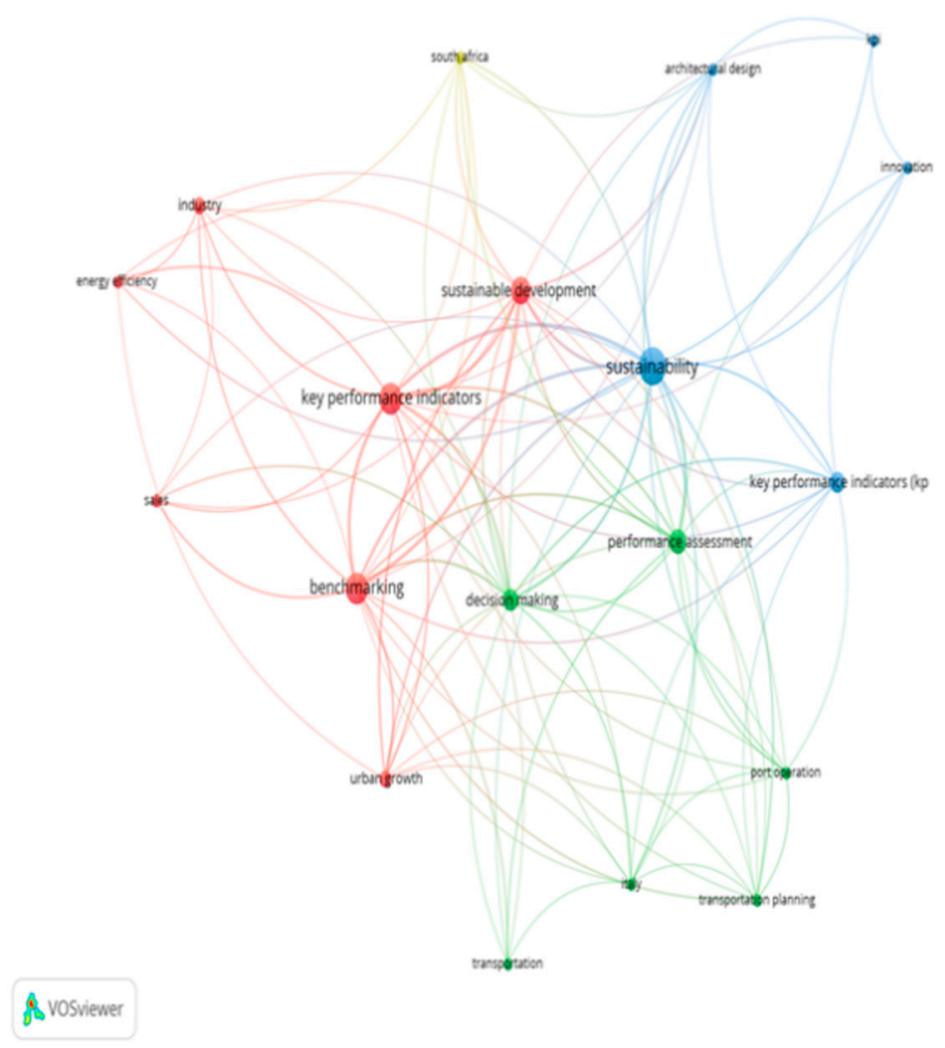

Figure 3. Recurring keywords.

Figure 4 shows all keywords that are individually interconnected under the form of bibliometric networks, such that each field of interest will be connected to the others. Accordingly, "sustainability" is strongly related to the terms "key performance indicators", "sustainable development", and "performance assessment". In the same way, "sustainable development" is related to "benchmarking", "decision making", "performance", and "sustainability". The relationships between "sustainability", "KPIs", "performance", and "system" represent the main areas of interest, and this connection indicates the relevant role of KPIs in evaluating and integrating sustainability in the strategies of the sample companies selected. Sustainable development plays a pivotal role, as observed by its strong interconnection with all relevant fields and keywords. Most of the papers focus on sustainable development related to company performance. 


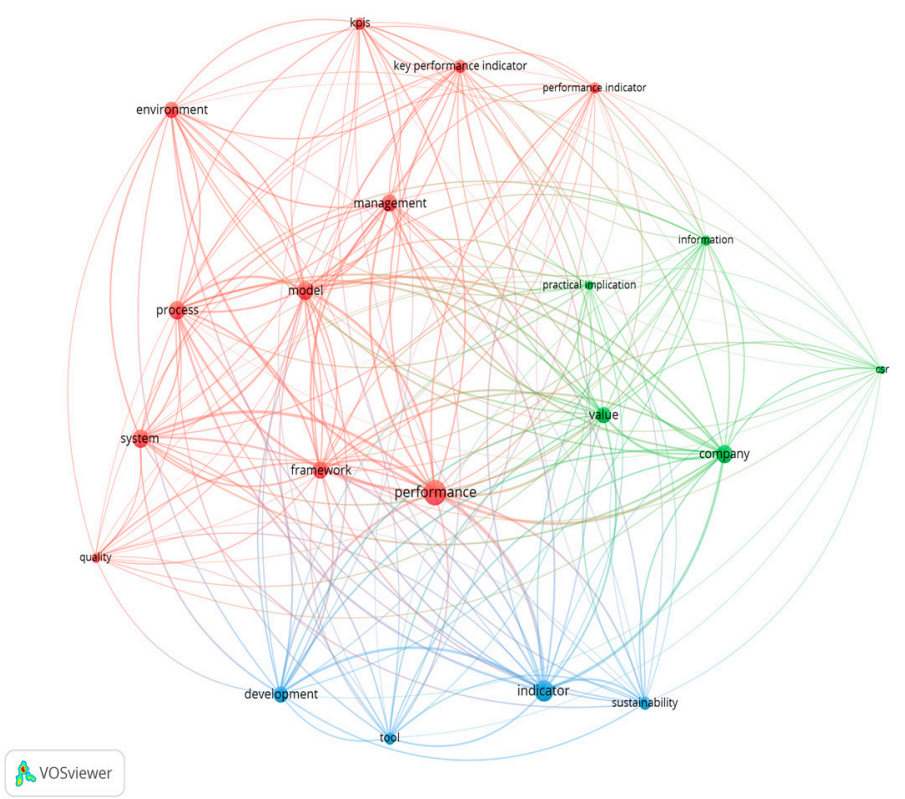

Figure 4. Co-occurring keywords.

Finally, it is also possible to see the most cited journals in the sample created by the system based on the selected scientific publications (Figure 5). In particular, the left side of Figure 5 shows journals with the most citations: the Journal of Cleaner Production (cited 81 times) and the International Journal of Productivity (cited 52 times). We can also see other journals with more citations, such as Long Range Planning (cited 48 times), International Journal of Supply Chain Management (cited 35 times), and Technological Forecasting (cited 26 times).

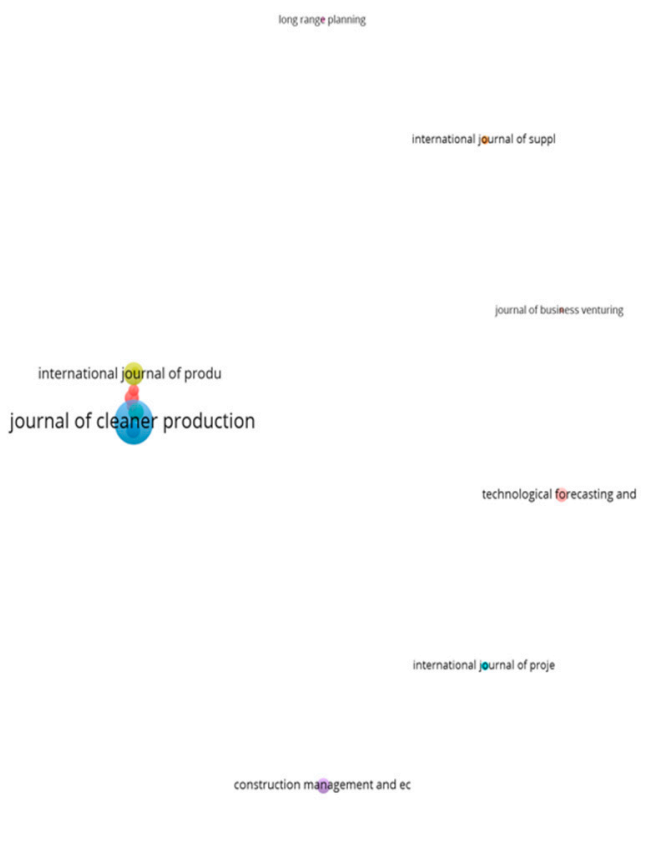

Figure 5. Recurring journals.

\subsection{Selection of Sustainability KPIs}

We analyzed all 82 papers, and for each sustainability dimension we identified a set of KPIs connected to a company's strategy in the value creation process. All authors skimmed the documents. They worked separately reading the papers and reported their main contents on a detailed table to 
discuss them together in a second step. The relevance of KPI systems is that they are specific strategic indicators enabling the measurement of future projects outcomes, positive or negative [44]. They are strictly correlated with corporate goals that must be achieved, and once each organization identifies its goals, the KPI system must be defined. Accordingly, the selection of KPIs to include should be: (1) correlated with organizational strategic objectives; (2) significant and effective to represent and explain the value creation process; and (3) reliable, comprehensive, consistent, and comparable. There is no specific limit in choosing KPIs beyond the relevant ones depending on the characteristics of each company. To this end, indicators should be selected to effectively summarize the company's situation and perspective. In this context, in addition to the papers obtained, we analyzed some of the most relevant reports on the topic provided by European and international organizations (Organization for Economic Co-operation and Development (OECD), US Environmental Protection Agency (EPA), etc.) and defined for each dimension the sustainable strategic goals and a set of KPIs connected to each of them.

\subsubsection{Environmental Performance Indicators}

The environment is the core of the sustainability dimension and represents the ability to safeguard the reproducibility of natural resources and preserve fundamental functions of the environment over time; hence it encompasses the fundamental role of natural resources and their use, and the reduction of nonrenewable resources and material degradation of nature and natural processes. In order to realize the new sustainability perspective, first it is necessary to define the environmental goals to achieve according to the SDGs. The strategic objectives are fundamental, since they allow us to identify strategies and create a guideline for the entire business process. For this reason, the Organization for Economic Co-operation and Development (OECD) provides a list of indicators that are neither conclusive nor comprehensive. The OECD has always been at the forefront in the area of environmental indicators, and during the 1990s the notion increasingly gained public attention, becoming a core issue among OECD countries, which then widely employed indicators for pollution issues and natural resources and assets. More specifically, in the first group, it is possible to recognize climate change by measuring $\mathrm{CO}_{2}$ and gas emissions, the ozone layer linked to indices on the apparent consumption of ozone depleting substances (ODS), air quality by computing $\mathrm{SO}_{\mathrm{x}}$ and $\mathrm{NO}_{\mathrm{x}}$ emissions, waste generation related to concerns about its intensity, and freshwater quality. The second group includes indicators such as freshwater resources for consumption and waste, climate change, fish resources, energy resources, and biodiversity for studies about threatened species (OECD, 2008). Additionally, the Environmental Quality Index, elaborated by the United States Environmental Protection Agency, considers seven environmental components: air, land, water, life environment, geological environment, nature, and forest. For each component, a simple index has been defined with a value between 0 and 1 to differentiate between the best possible and worst possible situations. The sum, equal to 100, sequentially defines the relative importance of each component (Environmental Protection Agency, 2014). Several authors have highlighted the relevance of environmental KPIs in implementing a sustainable strategy. Based on the papers analyzed, the most relevant environmental KPIs that impact value creation are connected to the following strategic items: (1) gas emissions; (2) renewable resources; (3) resource consumption; and (4) waste. One of the most important goals to achieve is to unify energy and climate, which will guarantee safe, economically accessible, and climate-friendly energy [45-47]. Fighting against climate change is, in fact, also a stimulus for employment and growth. Different sets of KPIs have been defined in the literature [48,49].

\subsubsection{Social Performance Indicators}

The second sustainability dimension analyzed here represents the capacity of providing for citizens' welfare with equal distribution among different classes. According to Guerci et al. [50], in this dimension stakeholders play a central role. In particular, compliance-oriented strategy has the explicit aim of including organizational and social goals into individuals' decision-making system. In addition, 
Oshika and Saka [11] highlighted the relevance of social indicators in the value creation process. Therefore, as for the environmental dimension, we selected strategic goals that best represent this perspective by identifying the following goals: (1) to encourage employees to accept cultural change; (2) to improve the quality of work conditions; (3) to guarantee respect for human rights; and (4) to participate in social initiatives. Researchers have discussed the fundamental role of social indicators that address social performance value. In particular, Omann and Spangenberg [50], in 2002, identified several social indicators associated with social resources, average time spent on voluntary activities, equal opportunities, cultural diversity, and so on. Husgafvel et al. [51] provided empirical evidence on the value creation impact of the occupational health and safety index, social innovations rate, and social sustainability index. Johansson et al. [52] focused on work performance indicators; Azapagic [53] and Krajnc and Glavič [54] focused on the employee satisfaction ratio and promotion rate. We selected all KPIs that positively impact a company's value. Figure 6 synthetizes all indicators selected, divided by strategic goals.
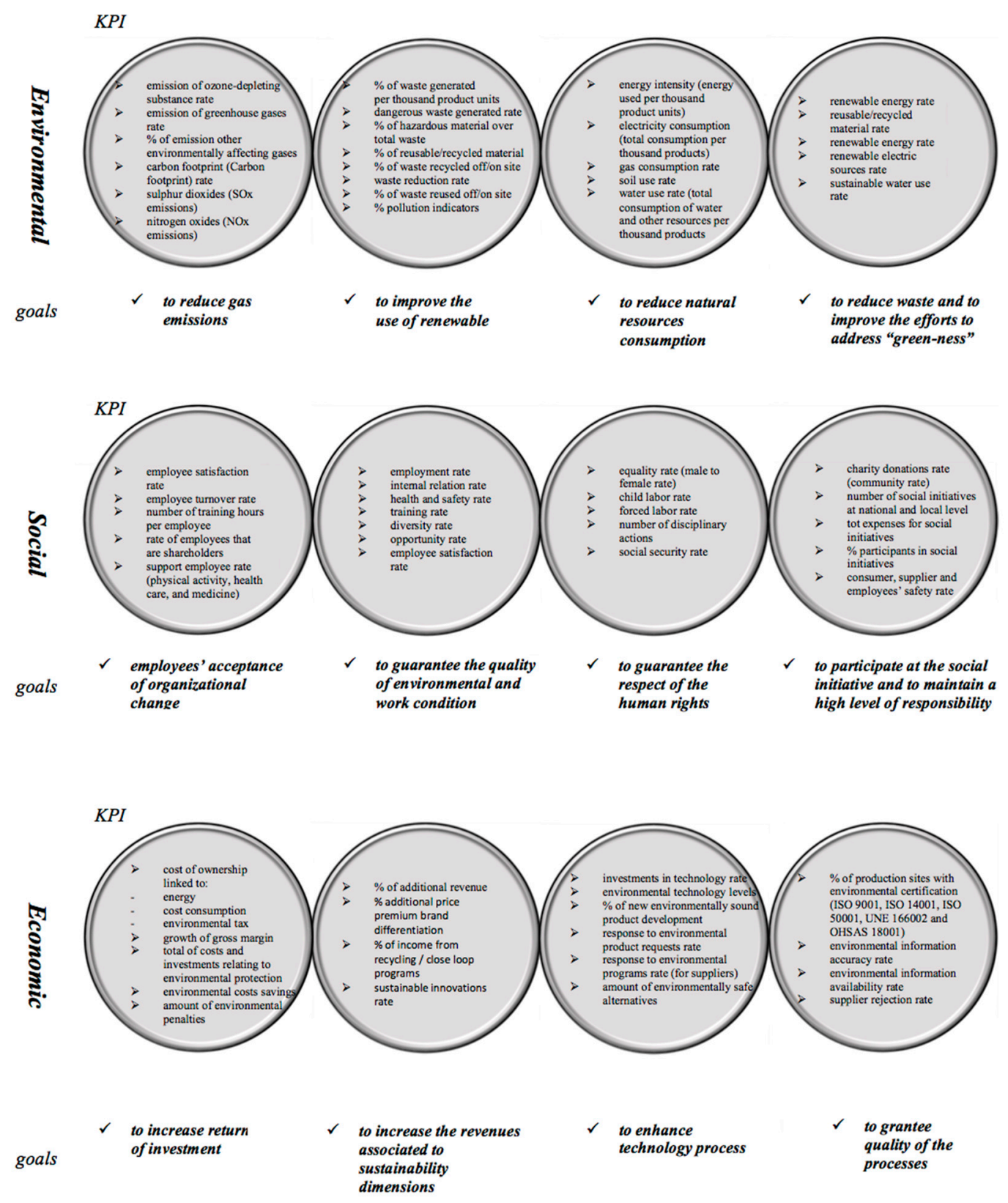

Figure 6. Sustainability performance indicators. (Appendix B). 


\subsubsection{Economic Performance Indicators}

Finally, the last key dimension we summarized was economic KPIs associated with sustainability issues. Particularly relevant are aspects covered at the World Summit on Sustainable Development in Johannesburg (2002), 10 years after the conference in Rio De Janeiro. It introduced for the first time the idea that economic growth is not a synonym for development, but it is fundamental to distinguish between growth and development. In fact, the summit drew attention to the fact that development must be considered a priority with respect to economic growth. Thus, three main pillars were established: social connection at the top, economic connection, and environmental connection [55]. In this case we refer to economics as the capacity to create durable growth of the main economic indicators, to generate revenue and employment, and to sustain the population, enhancing territorial uniqueness and efficiently employing resources [56]. For instance, Hsu et al. [57] focused on the growth of the gross margin ratio derived from the sustainability strategy adopted. Ferreira et al. [44] highlighted the need to consider the total costs and investments related to environmental protection. Van der Woerd [58] explained the relevance of financial indicators connected to sustainability in order to evaluate value creation. All KPIs selected in this dimension are shown in Figure 6. Moreover, according to Martínez-Perales et al. [1], there is a fundamental role of management system standards (ISO 9001, ISO 14001, ISO 50001, UNE 166002, and OHSAS 18001) that allow the application of sustainability issues to be certified and guarantee the high reputation of the company and respect for norms of each dimension. For example, respect for the economic dimension is guaranteed by ISO 9001 and UNE 166002, which allow the quality of financial and economic performance to be certified. At the same time, consideration of the environmental dimension is certified by ISO 14001 and ISO 50001, which allow the application of norms connected to the issues related to natural resources, environmental impact management, environmental policy management, and environmental commitment and responsibility to be guaranteed. Finally, consideration of the social dimension is guaranteed by ISO 9001, UNE 166002, and OHSAS 18001. A company's certifications have a direct influence on its performance and management. Therefore, there is a strong link between these standards and sustainability performance. To this end, the sustainability perspective needs to include all certifications that guarantee the quality and respect of sustainability dimensions. In addition, this allows the company to have a good reputation, improving relationships with and retention of clients. Since certification is given by competent external organizations, it is guaranteed that the information on management systems used is true and impartial.

\subsection{Interview Results}

According to the interviews, we analyzed the strategic sustainable goals, the use of sustainability KPIs, the advantages and benefits from implementing a sustainable strategy, and how to account for and integrate these aspects in the company's strategy from the practical point of view. We discussed with the managers the most relevant goals and KPIs that could allow integration of sustainability and strategy, and we created the sustainability perspective.

\subsubsection{Sustainable Goals}

We can identify five goals suggested by the interviewees to integrate the environmental dimension into the strategy. The goals most frequently identified were connected to the following aspects: (1) using renewable energy sources ( 25 managers, $100 \%$ ); (2) reducing the use of superfluous materials (23 managers, 92\%); (3) reducing greenhouse gases (22 managers, 88\%); (4) integrating environmental safeguards into government policies (16 managers, $64 \%$ ); and (5) adopting a sustainable and conscious lifestyle with respect to natural resources that is still effective in stimulating economic growth (16 managers, $64 \%$ ). With regard to the social dimension, the goals identified by the managers were connected to the following aspects: (1) including all members of society in the development of sustainable goals (21 managers, 84\%); (2) developing stakeholder relationships (18 managers, $72 \%$ ); (3) participating in social initiatives (18 managers, $72 \%)$; (4) including employees in the decision process 
(15 managers, 60\%); and (5) using social marketing policies (14 managers, 56\%). Finally, economic aspects that emerged from the interviews can be summarized as follows: (1) trends of financial indicators (25 managers, 100\%), (2) checks on product quality (24 managers, 96\%); (3) investing in professional training in research and development and marketing and communications (20 managers, $80 \%$ ); (4) the technological process (20 managers, $80 \%$ ); and (5) the quality of the process (18 managers, $72 \%)$. All goals are highlighted in Figure 7.

\begin{tabular}{|c|c|c|c|c|c|}
\hline Goal & frequency & $\%$ & KPI & frequency & $\%$ \\
\hline renewable energy sources & 25 & 100 & renewable sources rate & 25 & 100 \\
\hline reduction superfluous materials & 23 & 92 & efficiency materials use rate & 23 & 100 \\
\hline reduction greenhouse gasses & 22 & 88 & emissions greenhouse gasses rate & 18 & 72 \\
\hline environment's safeguard governmental policies & 16 & 64 & waste reduction rate & 16 & 64 \\
\hline lifestyles towards natural resources & 16 & 64 & recycled martials used rate & 16 & 64 \\
\hline $\begin{array}{l}\text { Inclusion of all society members in the development of } \\
\text { sustainable goals }\end{array}$ & 21 & 84 & integration rate & 21 & 84 \\
\hline stakeholder's relationship & 18 & 72 & stakeholder's satisfaction rate & 15 & 60 \\
\hline participation to the social initiative & 18 & 72 & $\begin{array}{l}\text { tot participation social initiatives at national and } \\
\qquad \text { local level }\end{array}$ & 14 & 56 \\
\hline inclusion of employees in the decision process & 15 & 60 & employee integration rate & 11 & 44 \\
\hline social marketing policies & 14 & 56 & customer satisfaction index & 10 & 40 \\
\hline trend of the financial indicators & 25 & 100 & ROI related to sustainable investments & 25 & 100 \\
\hline products quality & 24 & 96 & check on products quality & 21 & 84 \\
\hline $\begin{array}{l}\text { revenues invested in training, } \mathrm{R} \& \mathrm{D} \text {, Marketing and } \\
\text { Communication }\end{array}$ & 20 & 80 & revenues invested rate & 15 & 60 \\
\hline technology process & 20 & 80 & $\begin{array}{l}\text { ratio of investments to it, infrastructures and web } \\
\text { on total sales }\end{array}$ & 14 & 56 \\
\hline the quality of the process & 18 & 72 & $\begin{array}{l}\text { suitability and quality of the post-sale technical } \\
\text { assistance rate }\end{array}$ & 12 & 48 \\
\hline
\end{tabular}

Figure 7. Frequency distribution of key performance indicators (KPIs).

\subsubsection{Sustainable KPI System}

For each sustainability goal, we asked the interviewees to provide the most relevant indicators to consider when implementing a sustainable strategy. We considered the most frequent KPI for each strategic goal (based on the managers' answers on the first section of the questionnaire). Figure 7 shows our descriptive statistics results considering goals, frequency per goal, percentage based on total managers, KPIs, frequency per KPI, and percentage based on answers related to the goal. For example, taking into account the environmental section, all managers focused on the renewable sources rate to measure renewable energy sources. Regarding the reduction of superfluous materials, all managers who highlighted this goal (23 of 23) focused on the rate of efficient use of materials. For the third goal, reducing greenhouse gases, 18 managers $(72 \%)$ considered this indicator the best solution to implement and manage this critical aspect. For the last two goals of the environmental dimension, environmental safeguards and lifestyle toward natural resources, the indicators chosen were waste reduction $(64 \%)$ and use of recycled materials $(64 \%)$, respectively.

In defining goals and the consequent set of indicators, maintaining strategic coherence between the elements is of fundamental importance. The strategic objectives of the three aspects of sustainability exert a reciprocal influence: for example, obtaining a good employee satisfaction level and respect for company regulations leads to improved production processes, and this will allow the achievement of objectives connected to the economic dimension (reducing costs linked to failure to comply with regulations, improving structures and production processes, increasing customer satisfaction). At the same time, achieving the environmental goals (reducing emissions in relation to production volume, increasing the ratio between energy from renewable sources and energy used for production, reducing 
resource consumption, reducing the environmental impact of the supply chain) is strategically linked to the economic dimension: for example, reducing emissions reduces the risk of having penalties imposed by breaking regulations, and reducing resource consumption leads to a general reduction in costs, including those related to waste. This also has positive effects on social aspects, as it allows a healthier work environment for workers, reducing the causes of illness due to work and lowering the costs associated with absenteeism and medical care.

\section{Sustainability Perspective}

In the final step of our work, based on the literature and the contributions of the managers, we standardized and selected the most relevant and suitable KPIs connected to the value creation process. We thought about how to include these aspects in the strategy implementation. To this end, we discussed with the managers (final part of the questionnaire) how to account for the sustainability issues analyzed. We structured a sustainability perspective using the SBSC framework (Figure 7). Prior studies attempted to identify potential solutions to encapsulated sustainability dimensions in the strategy $[6,32,59]$. Although these papers contributed significantly, they did not focus on the practical aspects, which only the interviews allowed us to grasp [33,34]. One strength of the SBSC lies in its ability to bridge the gap between strategic and operative levels, identifying environmental and social aspects that are necessary to secure a company's financial success $[60,61]$. The SBSC is one of the most effective system in integrating all sustainability dimension and strategy [62-66].

The selection of KPIs depends on the type of company and its aims. The new perspective allows us to consider sustainability dimensions as an integral part of the strategy. All dimensions are considered, identifying for each of them: (1) strategic sustainability goals to achieve high performance; (2) the most relevant KPI to monitor and evaluate performance; (3) measures to calculate the chosen KPI; and (4) the target, or the level to achieve in order to guarantee success for the company, depending on its characteristics (Figure 8).

Accordingly, all objectives, KPIs, measures, and targets have to be defined and linked to long-term success and measured by the economic dimension. In this context, it is necessary to identify and determine the strategic relevance of the dimensions considered. Therefore, in this step, all aspects that affect the business unit and are strategically relevant need to be considered. In the last step, the sustainability perspective needs to be implemented in order to integrate its dimensions into the traditional financial aspects to achieve sustainable value creation.

Finally, it is important to point out that the proposed perspective was also designed in relation to the other conventional perspectives, including the critical; it cannot be denied, for example, that lowering costs due to sanctions can have a positive effect on the financial perspective, and the same could be said for increasing customer satisfaction, which would undoubtedly have a positive effect from the client's perspective, while increasing employee satisfaction would have a positive impact on internal processes, product quality, and the degree of customer satisfaction, and consequently the financial perspective. 


\begin{tabular}{|c|c|c|c|}
\hline \multicolumn{4}{|c|}{ Environmental } \\
\hline STRATEGIC GOAL & KPI & MEASUREMENT & TARGET \\
\hline $\begin{array}{l}\text { to improve the use of the } \\
\text { renewable } \\
\text { sources }\end{array}$ & renewable sources rate & renewable sources/other sources & \\
\hline $\begin{array}{l}\text { to reduce superfluous } \\
\text { resources consumption }\end{array}$ & efficiency resources use rate & $\begin{array}{l}\text { energy used per thousand product units } \\
(\mathrm{kWh} / 1000 \text { product units), total } \\
\text { consumption of water and other } \\
\text { resources per thousand products ( } \mathrm{l} / 1000 \\
\text { product units) }\end{array}$ & \\
\hline $\begin{array}{l}\text { to reduce greenhouse } \\
\text { gasses emissions }\end{array}$ & $\begin{array}{l}\text { total direct or indirect emissions } \\
\text { of greenhouse gases by weight }\end{array}$ & $\mathrm{CO} 2 / 1000$ products units & \\
\hline environment's safeguard & waste reduction rate & $\begin{array}{l}\text { percentage of waste generated per } \\
\text { thousand product units }\end{array}$ & \\
\hline $\begin{array}{l}\text { to improve the effort to } \\
\text { green-ness }\end{array}$ & $\begin{array}{l}\text { percentage of reusable/recycled } \\
\text { material }\end{array}$ & recycled material used/tot material used & \\
\hline \multicolumn{4}{|c|}{ Social } \\
\hline STRATEGIC GOAL & KPI & MEASUREMENT & TARGET \\
\hline $\begin{array}{l}\text { inclusion of all society } \\
\text { members in developing } \\
\text { sustainable goals }\end{array}$ & integration rate & questionnaire & \\
\hline stakeholders' relationship & stakeholders' satisfaction rate & questionnaire & \\
\hline $\begin{array}{l}\text { to participate at the social } \\
\text { initiatives }\end{array}$ & $\begin{array}{l}\text { n. social initiatives at national } \\
\text { and local level }\end{array}$ & $\begin{array}{l}\text { tot social initiatives at national and local } \\
\text { level }\end{array}$ & \\
\hline $\begin{array}{c}\text { to increase employees' } \\
\text { satisfaction }\end{array}$ & employee satisfaction rate & questionnaire & \\
\hline social marketing policies & customer satisfaction rate & cost analysis & \\
\hline \multicolumn{4}{|c|}{ Economic } \\
\hline STRATEGIC GOAL & KPI & MEASUREMENT & TARGET \\
\hline $\begin{array}{c}\text { to increase return of } \\
\text { investment }\end{array}$ & $\begin{array}{l}\text { ROI related to environmental } \\
\text { protection }\end{array}$ & cost analysis & \\
\hline $\begin{array}{l}\text { to increase the revenues } \\
\text { associated to } \\
\text { sustainability dimensions }\end{array}$ & $\begin{array}{l}\% \text { additional revenue (additional } \\
\text { price premium brand } \\
\text { differentiation, income from } \\
\text { recycling / close loop programs, } \\
\text { sustainable innovations) } \\
\end{array}$ & financial reporting & \\
\hline $\begin{array}{l}\text { to enhance technology } \\
\text { process }\end{array}$ & $\begin{array}{c}\% \text { of investments in } \\
\text { environmental technology }\end{array}$ & $\begin{array}{l}\text { investments in environmental } \\
\text { technology/tot investments }\end{array}$ & \\
\hline $\begin{array}{c}\text { to grantee the quality of } \\
\text { the process }\end{array}$ & $\begin{array}{l}\text { \% production sites with } \\
\text { environmental certification, } \\
\text { environmental information } \\
\text { accuracy rate, environmental } \\
\text { information availability rate } \\
\end{array}$ & survey & \\
\hline
\end{tabular}

Figure 8. The sustainability perspective. 


\section{Discussion and Final Remarks}

From the analysis adopted in this paper, several key concerns emerged with regard to a set of sustainability KPIs, the competitive advantages in applying a sustainable strategy, and the role of the SBSC framework to account for sustainability issues in strategy implementation.

In this context, is necessary to stimulate companies to adopt sustainability in their strategies. In fact, several studies have demonstrated how a sustainable strategy can positively affect company performance, underlining the advantages in terms of positive reputation and savings due to the efficiency of the resources used [63,64]. For example, Banyte et al. [65] stated that eco-compatibility helps companies recognize customers' new environmental awareness and can provide a real competitive advantage. The company's environmental awareness strengthens the process of employees identifying with the company, increasing their productivity and favoring the spread of a positive image. These effects, in turn, increase efficiency and sales. Miles et al. [62] showed even more markedly the benefits of a good reputation by considering the environmental dimension in the strategy. It has been shown $[67,68]$ that companies can benefit from being willing to pay attention to customers and a better working environment, and reducing risk due to customer loyalty, which is reflected in better financial performance. It has also been shown [62] that banks are prepared to grant loans with more favorable terms to "green" companies. Moreover, embracing a green strategy also means reducing costs, and therefore has a great impact on the economic performance of the company. In fact, reducing plant emissions is achieved mainly through more careful and efficient use of energy and/or using renewable energy sources. Both strategies involve reduced production costs and therefore increased profits. Furthermore, the green strategy also addresses product life cycles. Through the paradigm 'use-recycle-reuse', companies can recycle expensive materials and consequently save on the purchase of new ones. Xerox, for example, uses used photocopiers as a source of components for new machines through the asset recycle management (ARM) program, saving hundreds of millions of dollars [69]. This strategy is then publicized in the environmental report that the company provides every year together with the report for shareholders, as is done by many companies. The role of public institutions is crucial in stimulating the implementation of sustainable strategies. Many states influence corporate strategies through various regulations. They may be prohibitive or use incentives. In the first case, increasingly stringent regulations help companies to avoid damage to their image, creating limitations that, if respected, guarantee the good faith of the company. Moreover, it can favor the birth of new businesses by creating new business opportunities. Incentive measures, on the other hand, contribute to solving the problem of high development and production costs or energy efficiency that companies must face once they decide to take the path of sustainability.

Moreover, based on the questionnaires, we identified several issues that impact the value creation process (section 3 of the questionnaire); in particular, the increasing value of brand image and reputation by adopting a sustainable strategy. In fact, sustainable strategies promote brand value growth by reinforcing the company's identity, which increases the confidence of consumers and, in general, all of its stakeholders. To be able to increase loyalty, the organization must integrate effective social marketing policies that can strengthen intangible resources and transmit emotional value with a high positive impact on perceived value, in order to request a premium price due to the attention paid to sustainability. A further advantage of implementing sustainability comes from the reduction of operating costs in the social and environmental spheres. On the one hand, the reduction comes from a greater commitment by the staff to the cause of sustainability, since they are motivated and recognize themselves in the culture of a sustainable business. On the other hand, there is a reduction in cost due to the increased efficiency coming from waste reduction and optimized use of resources such as water and energy. These firms are, in general, more careful about the use of materials and the labor force. In addition, companies that voluntarily adopt sustainable strategies normally base their entire policy on transparency and trust, and this induces stakeholders to have more trust in the company, so the relationship is more lasting and reliable. Voluntarily adopting a sustainable strategy and going beyond regulatory obligations brings a better awareness of risk management, 
because companies that integrate environmental and social practices carry out more checks and management analyses than those that do not implement these practices. Moreover, companies that pay attention to sustainability are characterized by increased sales as a direct consequence of increased brand value, since consumers show a preference for products with less environmental impact and that are characterized by real social commitment. Thus, integrating sustainability into corporate strategy is really profitable. Finally, managers agree on attributing a central role of benefits concerning financial resources. A socially and environmentally responsible company can benefit from a particular subsidized source of financing, so as to be able to reduce financial charges on its own capital and consequently increase the value of the company. Similarly, the advantage for investors is to achieve greater returns, given the lower risk associated with sustainable businesses, as well as greater durability in the medium and long term.

In future research, it will be essential to test the model through a case study, by implementing it in a real context. This will represent an important step in increasing the implementation and diffusion of sustainability culture in companies that include SDGs in their business strategy. According to the European Commission (2019), sustainable development will better people's livelihoods, but the future of our planet requires immediate action. Therefore, the effort of each person and each company will be essential. Strong action is requested immediately, because if we continue in the same way, it will be too late for our planet. To this end, the role of the SBSC is relevant in driving companies in the "right" direction, considering value creation while respecting natural resources, to help the transition of the economy and society to a sustainable path.

Author Contributions: Although the work is a result of a joint efforts by all authors, the paper conceptualization and methodology are due to I.H., and funding acquisition and supervision to A.C. All authors were involved in writing the original draft, and specific sections can be attributed as follows: Section 1: I.H. and A.C.; Section 2: A.C.; Section 3: I.H.; Section 4: I.H.; Section 5: I.H. and A.C.

Funding: This research was funded by the University of Rome Tor Vergata, Department of Management and Law.

Acknowledgments: The authors would like to thank Dott. Giovanni Ciuchi for the cooperation, thoughtful support, collaboration, materials provided, and valuable comments, and also the University of Rome Tor Vergata, Department of Management and Law, for project funding.

Conflicts of Interest: The authors declare no conflict of interest. 


\section{Appendix A}

\section{Section 1 - Strategic Goals}

1. What are the main goals to include in the strategy in order to achieve sustainable performance?

2. Can you associated each goal to a specific dimension of sustainability?

3. Did strategy change with respect to the sustainability performance? Can you explain how?

4. Accordingly, managers are interested to the sustainability issues?

5. Do you think that the consideration of sustainability issues could add value of the performance of the companies?

6. in your opinion is it possible to integrate sustainability to the financial performance? How?

\section{Section 2 - Sustainability KPIs}

7. For each of the sustainability dimensions identified, could you talk about the most relevant indicators to consider in implementing sustainable strategy related to the goals identified?

8. How do you measure each indicator?

9. What about the target?

10. Well, based on your experience what do you think about the indicators identified in the literature? (we show a set of KPI for each dimension)

\section{Section 3 - Competitive advantages}

11. Can you explain how the use of sustainable KPIs impact on value creation process?

12. What are the main advantages in using sustainable strategy?

13. How do you measure this advantages?

\section{Section 4-SBSC role}

14. What do you think about the role of SBSC in considering sustainability dimensions?

15. In your opinion could be useful? How? Can you explain?

16. How do you integrate sustainability dimensions in the SBSC?

Figure A1. Questionnaire.

\section{Appendix B}

Table below cites the most relevant papers used to select the KPIs for each dimension. 


\begin{tabular}{|c|c|c|}
\hline References used & Sustainability dimension & $\begin{array}{c}\text { KPIs } \\
\text { selected }\end{array}$ \\
\hline $\begin{array}{l}\text { Leksono et al. (2019); Rosenfeld et al. (2019); Amrina et } \\
\text { al. (2019); Sulewski et al. (2018); Di Vaio et al. (2018); } \\
\text { Sujit et al. (2018); Sislian and Jaegler. (2018); Hsu et al. } \\
\text { (2017); Rajnoha et al. (2017); Jalkanen et al. (2016); } \\
\text { Antāo et al. (2016); Puente- Rodnguez et al. (2016), } \\
\text { Laxe et al. (2016); Seguí et al. (2016); Winroth et al. } \\
\text { (2016); Puig et al. (2014); Winroth et al. (2014); } \\
\text { Chardine-Baumann and Botta-Genoulaz (2014); } \\
\text { Guerci et al. (2014); Joung et al. (2013); Epstein and } \\
\text { Wisner (2001); Shen et al. (2013); Govindan et al. } \\
\text { (2013); Lirn etal. (2013); Azadnia et al. (2012); Amrina } \\
\text { and Yusof (2011); Fan et al. (2010); Perotto et al. } \\
\text { (2008); Young and Kielkiewicz-Young (2001); Rao } \\
\text { (2002); Azapagic and Perdan (2000); }\end{array}$ & Environmental & $\begin{array}{l}\% \text { of waste generated per thousand } \\
\text { product units, grenhouse gases rate, } \\
\text { hazardous material ratio, dangerous } \\
\text { waste genemated rate, energy intensity, } \\
\text { electricity consumption nate, gas } \\
\text { consumption mate, soil use nute, water } \\
\text { use rate, amount of environmental } \\
\text { penaltics, environmentally affecting } \\
\text { gases, carbon footprint rate, stuphur } \\
\text { dioxides (SOX emissions), nitrogen } \\
\text { oxides (NOx amissions), \% pollution } \\
\text { indicators }\end{array}$ \\
\hline $\begin{array}{l}\text { Hristov et al. (2019); Leksono et al. (2019); Amrina et } \\
\text { al. (2019); Suryanto et al. (2018); Malthouse et al. } \\
\text { (2013); Haghighi et al. (2016); Ferreira et al. (2016); } \\
\text { Huang et al. (2014); Chardine-Baumann and Botta- } \\
\text { Genoulaz (2014); Beske et al. (2014); Varsei et al. } \\
\text { (2014); Husgafvel et al. (2013); Peters (2013); Ahi and } \\
\text { Searcy (2013); Azadnia et al. (2012); Grigoroudis et al. } \\
\text { (2012); Cabral et al. (2012); Zhao et al. (2012); } \\
\text { Govindan et al. (2013); Johansson et al. (2012); Amrina } \\
\text { and Yusof (2011); Chia et al. (2009); Crespo et al. } \\
\text { (2009); Adams (2008); Lee et al. (2007); Angerhofer et } \\
\text { al. (2006); Krajnc et al. (2004); Chan et al. (2004); } \\
\text { Azapagic et al. (2004); Fan et al. (2010); Heikkilă } \\
\text { (2002); Gunasekaran et al. (2001); Omann et al. (2002); } \\
\text { Littig (2001); Azapagic and Perdan (2000); Kopfmüller } \\
\text { (2000); Empacher and Wehling (1999); Pissarides et al. } \\
\text { (1999); }\end{array}$ & Social & 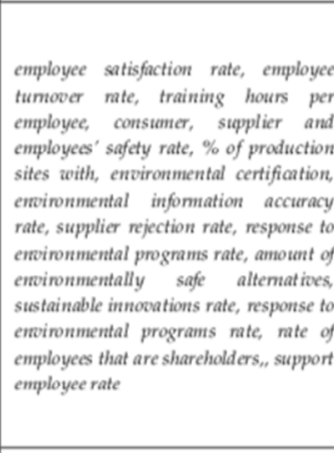 \\
\hline $\begin{array}{l}\text { Hristov et al. (2019); Amrina et al. (2019); Leksono et } \\
\text { al. (2019); Puig et al. (2017); Ha et al. (2017); Xiao and } \\
\text { Lam (2017), Tichavska and Tovar (2017); Roos and } \\
\text { Neto (2017); Puig et al. (2017); Hsu et al. (2017); } \\
\text { Ferreira et al. (2016); Govindan et al. (2016); Chardine- } \\
\text { Baumann and Botta-Genoulaz (2014); Tajbakhsh and } \\
\text { Hassini (2014); Govindan et al. (2013); Moniem et al. } \\
\text { (2013); Amindoust et al., (2012); Pham and Thomas } \\
\text { (2012); Azadnia et al. (2012); Olugu and Wong (2012); } \\
\text { Crespo et al. (2009); Peris-Mora et al. (2005); Amrina } \\
\text { and Yusof (2011); Fan et al. (2010); Woerd and Brink } \\
\text { (2004); Azapagic and Perdan (2000); }\end{array}$ & Economic & 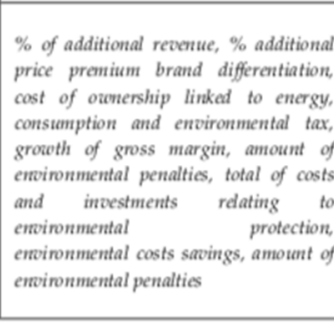 \\
\hline
\end{tabular}

Figure A2. References used.

\section{References}

1. Martínez-Perales, S.; Ortiz-Marcos, I.; Juan Ruiz, J.; Lázaro, F. Using Certification as a Tool to Develop Sustainability in Project Management. Sustainability 2018, 10, 1408. [CrossRef]

2. European Union. A Sustainable Bioeconomy for Europe: Strengthening the Connection between Economy, Society and the Environment; Directorate-General for Research and Innovation: Brussels, Belgium, 2018.

3. Elkington, J. Cannibals with Forks: The Triple Bottom Line of 21st Century Business; Capstone: Oxford, UK, 1997; p. 402. ISBN 1-900961-27-X.

4. Adams, W.M. The Future of Sustainability: Re-Thinking Environment and Development in the Twenty-First Century; Report IUCN: Zurich, Switzerland, 2006.

5. Van den Brink, J.; Silvius, G.; Köhler, A. The impact of sustainability on PM. In Anonymous; Monash University Publishing: Clayton, Australia, 2012; pp. 183-200.

6. Hristov, I.; Chirico, A.; Appolloni, A. Sustainability Value Creation, Survival, and Growth of the Company: A Critical Perspective in the Sustainability Balanced Scorecard (SBSC). Sustainability 2019, 11, 211. [CrossRef]

7. Briassoulis, H. Sustainable Development-The Formal or Informal Way? In Environmental Politics in Southern Europe; Springer: Dordrecht, The Netherlands, 2001; pp. 73-99. [CrossRef]

8. Burritt, R.; Saka, C. Environmental management accounting applications and eco-efficiency: Case studies from Japan. J. Clean. Prod. 2006, 14, 1262-1275. [CrossRef]

9. Adams, C.A.; McNicholas, P. Making a difference. Account. Audit. Account. J. 2007, 20, 382-402. [CrossRef]

10. Bebbington, J.; Higgins, C.; Frame, B. Initiating sustainable development reporting: Evidence from New Zealand. Account. Audit. Account. J. 2009, 22, 588-625. [CrossRef]

11. Saka, C.; Oshika, T. Disclosure effects, carbon emissions and corporate value. Sustain. Account. Manag. Policy J. 2014, 5, 22-45. [CrossRef] 
12. Hart, S. A natural-resource-based view of the firm. Acad. Manag. Rev. 1995, 20, 986-1014. [CrossRef]

13. Hart, S. Beyond greening: Strategies for a sustainable world. Harv. Bus. Rev. 1997, 75, 66-76.

14. Roome, N.J. Sustainability Strategies for Industry: The Future of Corporate Practice; Island: Washington, DC, USA, 1998.

15. Schaltegger, S.; Burritt, R. Contemporary Environmental Accounting: Issues, Concepts and Practice; Greenleaf: Sheffield, UK, 2000.

16. Bennett, M.; James, P. Sustainable Measures: Evaluation and Reporting of Environmental and Social Performance; Greenleaf: Sheffield, UK, 1999.

17. Kaplan, R.S.; Norton, D.P. Linking the Balanced Scorecard to Strategy. Calif. Manag. Rev. 1997, 39, 53-798. [CrossRef]

18. Braam, G.J.M.; Nijssen, E.J. Performance effects of using the Balanced Scorecard: A note on the Dutch experience. Long Range Plan. 2004, 37, 335-349. [CrossRef]

19. Kraus, K.; Lind, J. The impact of the corporate balanced scorecard on corporate control—A research note. Mansg. Account. Res. 2010, 21, 265-277. [CrossRef]

20. Barnabe, F.; Busco, C. The Causal Relationships between Performance Drivers and Outcomes: Reinforcing Balanced Scorecards' Implementation through System Dynamics Models. J. Account. Organ. Chang. 2012, 8, 528-538. [CrossRef]

21. Epstein, M.J.; Wisner, P.S. Good neighbors: Implementing social and environmental strategies with the BSC. Balanc. Scorec. Rep. 2001, 3, 8-11.

22. Hervani, A.; Helms, M.; Sarkis, J. Performance measurement for green supply chain management. Benchmarking 2005, 12, 330-353. [CrossRef]

23. Duman, M.; Taskaynatan, M.; Kongar, E.; Rosentrater, A. Integrating Environmental and Social Sustainability into Performance Evaluation: A Balanced Scorecard-Based Grey-DANP Approach for the Food Industry. Front. Nutr. 2018, 5, 65. [CrossRef]

24. Figge, F.; Hahn, T.; Schaltegger, S.; Wagner, M. Sustainability Balanced Scorecard. Linking Sustainability Management to Business Strategy. Bus. Strateg. Environ. 2002, 11, 269-284. [CrossRef]

25. Searcy, C.; Buslovich, R. Corporate perspectives on the development and use of Sustainability reports. J. Bus. Ethics 2014, 121, 149-169. [CrossRef]

26. Tranfield, D.; Denyer, D.; Smart, P. Towards a Methodology for Developing Evidence-Informed Management Knowledge by Means of Systematic Review. Br. J. Manag. 2003, 14, 207-222. [CrossRef]

27. Fink, A. Conducting Research Literature Reviews: What Did You Find? 3rd ed.; Sage Publications Inc.: Thousand Oaks, CA, USA, 2009.

28. Littell, J.H.; Corcoran, J.; Pillai, V. Systematic Reviews and Meta-analysis; Oxford University Press: New York, NY, USA, 2008.

29. Seuring, S.; Müller, M. From a literature review to a conceptual framework for sustainable supply chain management. J. Clean. Prod. 2008, 16, 1699-1710. [CrossRef]

30. Pickering, C.; Byrne, J. The benefits of publishing systematic quantitative literature reviews for $\mathrm{PhD}$ candidates and other early-career researchers. High. Educ. Res. Dev. 2014, 33, 534e548. [CrossRef]

31. Brown, D. Organizational Culture, 2nd ed.; Financial Times/Prentice Hall: Callaghan, NSW, Australia, 1998; p. 336.

32. Hansen, E.; Schaltegger, S. The sustainability balanced scorecard: A systematic review of architectures. J. Bus. Ethics 2016, 133, 193-221. [CrossRef]

33. Evans, J.H.; Feng, M.; Hoffman, V.B.; Moser, D.V.; van der Stede, W.A. Points to Consider When Self-Assessing Your Empirical Accounting Research. Contemp. Acc. Res. 2015, 32, 1162-1192. [CrossRef]

34. Dai, N.T.; Free, C.; Gendron, Y. Interview-based research in accounting 2000-2014: Informal norms, translation and vibrancy. Manag. Account. Res. 2019, 42, 26-38. [CrossRef]

35. Bortolotti, T.; Boscari, S.; Danese, P. Successful lean implementation: Organizational culture and soft lean practices. Int. J. Prod. Econ. 2015, 160, 182-201. [CrossRef]

36. Eisenhardt, K.M.; Graebner, M.E. Theory Building from Cases: Opportunities and Challenges. Acad. Manag. J. 2007, 50, 25-32. [CrossRef]

37. Sousa, R.; Voss, C.A. Contingency research in operations management practices. J. Oper. Manag. 2008, 26, 697-713. [CrossRef] 
38. Kohlbacher, F. The use of qualitative content analysis in case study research. Forum Qual. Soci. Res. 2006, 7, 21.

39. Jarden, R.J.; Narayanan, A.; Sandham, M.; Siegert, R.J.; Koziol-Mclain, J. Bibliometric mapping of intensive care nurses' wellbeing: Development and application of the new Analysis model. BMC Nurs. 2019, 18, 1-11. [CrossRef]

40. Kamdem, J.P.; Duarte, A.E.; Lima, K.R.R.; Rocha, J.B.T.; Hassan, W.; Barros, L.M.; Roeder, T.; Tsopmo, A. Research trends in food chemistry: A bibliometric review of its 40years anniversary (1976-2016). Food Chem. 2019, 294, 448-457. [CrossRef]

41. Lawal, I.A.; Klink, M.; Ndungu, P.; Moodley, B. Brief bibliometric analysis of “ionic liquid" applications and its review as a substitute for common adsorbent modifier for the adsorption of organic pollutants. Environ. Res. 2019, 175, 34-51. [CrossRef]

42. Martinez, S.; del Mar Delgado, M.; Marin, R.M.; Alvarez, S. Science mapping on the Environmental Footprint: A scientometric analysis-based review. Ecol. Indic. 2019, 106, 105543. [CrossRef]

43. Bell, S.; Morse, S. Sustainability Indicators Past and Present: What Next? Sustainability 2018, 10, 1688. [CrossRef]

44. Ferreira, L.M.D.F.; Silva, C.; Azevedo, S.G. An environmental balanced scorecard for supply chain performance measurement (Env_BSC_4_SCPM). Benchmarking Int. J. 2016, 23, 1398-1422. [CrossRef]

45. Rajnoha, R.; Lesníková, P.; Krajčík, V. Influence of business performance measurement systems and corporate sustainability concept to overall business performance: Save the planet and keep your performance. $E+M$ Ekon. Manag. 2017, 20, 111-128. [CrossRef]

46. Di Vaio, A.; Varriale, L.; Alvino, F. Key performance indicators for developing environmentally sustainable and energy efficient ports: Evidence from Italy. Energy Policy 2018, 122, 229-240. [CrossRef]

47. Joung, C.B.; Carrell, J.; Sarkar, P.; Feng, S.C. Categorization of indicators for sustainable manufacturing. Ecol. Indic. 2013, 24, 148-157. [CrossRef]

48. Winroth, M.; Alamström, P.; Andersson, C. Indicators of sustainable production-A survey among Swedish manufacturing industry. In Proceedings of the 1st EurOMA Sustainable OM \& SCM Forum, Groningen, The Netherlands, 23-25 March 2014.

49. Guerci, M.; Radaelli, G.; Siletti, E.; Cirella, S.; Rami Shani, A.B. The Impact of Human Resource Management Practices and Corporate Sustainability on Organizational Ethical Climates: An Employee Perspective. J. Bus. Ethics 2014, 126, 325-342. [CrossRef]

50. Omann, I.; Spangenberg, J.H. Assessing social sustainability. In Proceedings of the Biennial Conference of the International Society for Ecological Economics, Sousse, Tunisia, North Africa, 6-9 March 2002.

51. Husgafvel, R.; Watkins, G.; Linkosalmi, L.; Dahl, O. Review of sustainability management initiatives within Finnish forest products industry companies-Translating Eu level steering into proactive initiatives. Resour. Conserv. Recycl. 2013, 76, 1-11. [CrossRef]

52. Johansson, B.; Dagman, A.; Rex, E.; Nystrom, T.; Wedel, M.K.; Stahre, J.; Soderberg, R. Sustainable production research: Awareness, measures and development. OIDA Int. J. Sustain. Dev. 2012, 4, 95-104.

53. Azapagic, A. Developing a framework for sustainable development indicators for the mining and minerals industry. J. Clean. Prod. 2004, 12, 639-662. [CrossRef]

54. Krajnc, D.; Glavic, P. Indicators of Sustainable Production; Springer: Berlin/Heidelberg, Germany, 2004.

55. UN World Summit on Sustainable Development (WSSD). Johannesburg Declaration and Plan of Implementation; International Documents on Corporate Responsibility; Edward Elgar Publishing: Cheltenham, UK, 2002. [CrossRef]

56. Simmonds, N.W. Building a Sustainable Society. By Lester, R.B. New York and London: Norton, p. 433. Exp. Agric. 1983, 19, 111. [CrossRef]

57. Hsu, C.-H.; Chang, A.-Y.; Luo, W. Identifying key performance factors for sustainability development of SMEs-Integrating QFD and fuzzy MADM methods. J. Clean. Prod. 2017, 161, 629-645. [CrossRef]

58. Woerd, F.V.D.; van den Brink, T. Feasibility of a Responsive Business Scorecard? A pilot study. J. Bus. Ethics 2004, 55, 173-186. [CrossRef]

59. Hahn, T.; Figge, F. Why Architecture Does Not Matter: On the Fallacy of Sustainability Balanced Scorecards. J. Bus. Ethics 2018, 150, 919-935. [CrossRef]

60. Falle, S.; Rauter, R.; Engert, S.; Baumgartner, R. Sustainability Management with the Sustainability Balanced Scorecard in SMEs: Findings from an Austrian Case Study. Sustainability 2016, 8, 545. [CrossRef] 
61. Searcy, C. Corporate sustainability performance measurement systems: A review and research agenda. J. Bus. Ethics 2012, 107, 239-253. [CrossRef]

62. Nandy, M.; Lodh, S. Do banks value the eco-friendliness of firms in their corporate lending decision? Some empirical evidence. Int. Rev. Financ. Anal. 2012, 25, 83-93. [CrossRef]

63. Demartini, M.; Pinna, C.; Aliakbarian, B.; Tonelli, F.; Terzi, S. Soft Drink Supply Chain Sustainability: A Case Based Approach to Identify and Explain Best Practices and Key Performance Indicators. Sustainability 2018, 10, 3540. [CrossRef]

64. Burger, N.; Demartini, M.; Tonelli, F.; Bodendorf, F.; Testa, C. Investigating Flexibility as a Performance Dimension of a Manufacturing Value Modeling Methodology (MVMM): A Framework for Identifying Flexibility Types in Manufacturing Systems. Procedia CIRP 2017, 63, 33-38. [CrossRef]

65. Gadeikienè, A.; Banyte, J. Discourse on Corporate Social Responsibility in the Context of Marketing Scientific Research. Procedia Soci. Behav. Sci. 2015, 213, 702-708. [CrossRef]

66. Miles, M.P.; Covin, J.G.J. Environmental Marketing: A Source of Reputational, Competitive, and Financial Advantage. J. Bus. Ethics 2000, 23, 299-311. [CrossRef]

67. Fombrun, C.; Shanley, M. What's in a name? Reputation building and corporate strategy. Acad. Manag. J. 1990, 33, 233-258.

68. Fombrun, C. Reputation. Wiley Encycl. Manag. 2015, 5, 1-3. [CrossRef]

69. Hart, J.F. Colonial Land Use Law and Its Significance for Modern Takings Doctrine. Harv. Law Rev. 1996, 109, 1252. [CrossRef]

(C) 2019 by the authors. Licensee MDPI, Basel, Switzerland. This article is an open access article distributed under the terms and conditions of the Creative Commons Attribution (CC BY) license (http://creativecommons.org/licenses/by/4.0/). 